\title{
Crude glycerin in meat goat diets: intake, performance and carcass traits
}

\section{Glicerina bruta na dieta de caprinos de corte: consumo, desempenho e características de carcaça}

\author{
Juliano Cesar Dias ${ }^{\mathrm{I}}$ André Luís Finkler da Silveira ${ }^{\mathrm{II}}$ José Antonio Cogo Lançanova ${ }^{\mathrm{II}}$ \\ João Ari Gualberto Hill ${ }^{I I}$ José Luiz MolettaII
}

\section{ABSTRACT}

This experiment aimed to evaluate the effect of including glycerin in kid goats diet on intake, performance and carcass traits. Twenty intact male kid goats Boer crossbred were used, with body weight of $25.06 \pm 4.15 \mathrm{~kg}$ and $8.00 \pm 0.66$ months old, allocated in block design, with four treatments and five replicates. The treatments consisted on including dry matter basis (DM) of the diet of four levels of glycerin: zero, five, 10 and $15 \%$, in replacing corn. It was not reported influence $(P>0.05)$ of level of glycerin on intake of forage and feed conversion of animals. The concentrate and total DM intake were affected $(P<0.05)$ for the level of glycerin in DM, with reduction in the animals that received the highest level. It was not reported influence $(P>0.05)$ of level of glycerin on weight gain, carcass yield and percentage of cooling losses. However, the hot and cold carcass weight was lower $(P<0.05)$ to the animals feed with $15 \%$ of glycerin. The inclusion up to $15 \%$ of glycerin in the diet of kid goats Boer crossbred, although did not affect feed conversion and performance, compromised the intake and carcass weight.

Key words: boer, body weight, glycerol, kid goat.

\section{RESUMO}

Objetivou-se avaliar o efeito da inclusão de glicerina na dieta de cabritos sobre o consumo, desempenho e características de carcaça. Foram utilizados 20 cabritos não castrados, mestiços Boer, com peso corporal médio de

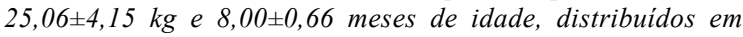
blocos ao acaso, com quatro tratamentos e cinco repetições. Os tratamentos consistiram da inclusão de glicerina $187 \%$ de glicerol) na dieta, em substituição ao milho, em quatro niveis de concentração: zero, cinco, 10 e 15\% na matéria seca (MS). Não foi encontrada influência $(P>0,05)$ da glicerina na dieta sobre o consumo de volumoso e a conversão alimentar. Os consumos de concentrado e de MS total foram afetados $(P<0,05)$ pelo nivel de glicerina na $\mathrm{MS}$, com redução nos animais que receberam o mais alto nível. Não houve efeito $(P>0,05)$ dos níveis de glicerina para ganho de peso, rendimento de carcaça e perdas por resfriamento. Entretanto, houve efeito $(P<0,05)$ para peso da carcaça quente e fria para os animais alimentados com $15 \%$ de glicerina. A inclusão de até $15 \%$ de glicerina na dieta de cabritos mestiços Boer, embora não afete a conversão alimentar e o desempenho, compromete o consumo e o peso da carcaça dos animais.

Palavras-chave: boer, cabrito, glicerol, peso corporal.

\section{INTRODUCTION}

The increasing demand for the intensification of production systems, aiming at greater efficiency, has boosted the employment of technologies; in this context, the use of coproducts from agroindustry for ruminants feed is an efficient form to decrease production costs and improve the profitability of systems (JESUS et al., 2010; PALMIERI et al., 2012).

Production of biodiesel has been increasing exponentially over the past few years leading to the generation of greater amounts of coproducts, which have an economic and eco-friendly destination (LAGE et al., 2010). Important aspects involve the biodiesel chain in Brazil, with emphasis to matters related to raw material and industrial production process. Biodiesel is manufactured through transesterification, in which glycerin is separated from the fat or vegetable oil. The

IUniversidade Federal da Fronteira Sul (UFFS), BR 158, Km 405, CP 106, 85301-000, Laranjeiras do Sul, PR, Brasil. E-mail: julianocdias@yahoo.com.br. Corresponding author.

"Instituto Agronômico do Paraná (IAPAR), Londrina, PR, Brasil. 
process generates two products: esters and glycerin; in addition to coproducts (cake, bran, etc.) that may represent other important income sources for producers (ABDALLA et al., 2008).

Among the possible uses of glycerin generated during biodiesel production, it can be highlighted its application in the feed for ruminants since it constituted an energy-rich product $(4.320 \mathrm{kcal}$ of crude energy $\mathrm{kg}^{-1}$ for pure glycerol) with high utilization efficiency (MENTEN et al., 2008) able to replace corn in a diet and reduce production costs.

Glycerol is absorbed directly through the rumen epithelium, metabolized in the liver and directed to gluconeogenesis by the action of enzyme glycerol kinase, which converts it into glucose. Part of glycerol can be fermented with propionate, in the rumen, which is, in turn, metabolized with oxaloacetate in the liver through the Krebs cycle, and can be used to for glucose through the gluconeogenic via (LAGE et al., 2010).

The objective of this study was to assess the inclusion of different levels of glycerin in the diet of meat goats regarding intake, feed conversion, performance, and carcass traits.

\section{MATERIALS AND METHODS}

The feeding trial experiment was conducted at the Regional Research Unit of the Southwest belonging to the Agronomic Institute of
Paraná, city of Pato Branco, Paraná State, Brazil. Twenty intact male kid goats Boer crossbred were used, with body weight of $25.06 \pm 4.15 \mathrm{~kg}$ and $8.00 \pm 0.66$ months old, distributed in block design, with four treatments and five replicates.

The animals were allocated in individual pens, and were allowed ad libitum access to clean drinking water and troughs. The forage to concentrate ratio of the diets were, $45 \%$ forage (Tifton- 85 hay) and $55 \%$ concentrate, on dry matter (DM) basis. Treatments consisted of glycerin inclusion $(87 \%$ glycerol, obtained from soybean oil) in the diet in replacing corn, in four levels, being zero, five, 10 and $15 \%$ in the DM of the diet (Table 1). The diets were formulated to be isoproteic and isoenergetic in order to meet the nutritional demands of a kid goat weighting $25 \mathrm{~kg}$ of body weight, with an average daily weight gain of $200 \mathrm{~g}$ (NRC, 2007). Animals were subject to a 10 days period of adaptation and weighted after a 16 hours fasting at the beginning and in the end of the experimental period. The intermediate weighing was conducted within 15 days intervals, before the first meal of the day to correct the offer of food. The experimental period lasted for 68 days, and the animals were dewormed at the beginning and 30 days later.

Animals were fed with concentrate twice a day, at 09:30 am and 4:00 pm; the leftovers were collected and weighted on a daily basis. The concentrate

Table 1 - Feed name and bromatological composition of experimental diets, on dry matter (DM) basis.

\begin{tabular}{|c|c|c|c|c|c|}
\hline & \multirow{2}{*}{ Hay } & \multicolumn{4}{|c|}{--Concentrate (\%) } \\
\hline & & 0 & 5 & 10 & 15 \\
\hline \multicolumn{6}{|c|}{ } \\
\hline Grinded corn & . & 34.3 & 22.6 & 10.9 & 0.0 \\
\hline Soybean bran & . & 25.9 & 28.0 & 30.0 & 31.7 \\
\hline Wheat bran & . & 34.1 & 34.1 & 34.1 & 33.8 \\
\hline Mineral salt & . & 1.9 & 1.9 & 1.9 & 1.9 \\
\hline Regular salt & . & 0.9 & 0.9 & 0.9 & 0.9 \\
\hline Limestone & . & 2.8 & 3.4 & 4.0 & 4.7 \\
\hline Glycerin & . & 0.0 & 9.1 & 18.2 & 27.0 \\
\hline Crude protein (CP) & 14.3 & 24.6 & 25.9 & 26.7 & 25.4 \\
\hline $\mathrm{NDF}$ & 80.0 & 21.0 & 18.5 & 20.2 & 19.2 \\
\hline $\mathrm{ADF}$ & 37.8 & 7.9 & 7.3 & 6.2 & 7,2 \\
\hline NDIP (\% CP) & 49.2 & 9.1 & 7.8 & 8.7 & 8.2 \\
\hline $\mathrm{ADIP}(\% \mathrm{CP})$ & 4.1 & 4.5 & 3.1 & 2.3 & 2.5 \\
\hline TDN & 60.0 & $72.7^{*}$ & $72.2^{*}$ & $71.6^{*}$ & $71.2^{*}$ \\
\hline
\end{tabular}

OBS: $\mathrm{NDF}=$ neutral detergent fiber; $\mathrm{ADF}=$ acid detergent fiber; NDIP $=$ neutral detergent insoluble protein; $\mathrm{ADIP}=$ acid detergent insoluble protein; TDN $=$ total digestive nutrients. ${ }^{*}$ Estimated through the bromatological composition of foods $-\mathrm{TDN}(\%)=[\mathrm{TDN}$ Grinded corn $\left.(\mathrm{kg})+\mathrm{TDN}_{\text {Soybean bran }}(\mathrm{kg})+\mathrm{TDN}_{\text {Wheat bran }}(\mathrm{kg})+\mathrm{TDN}_{\text {Glycerin }}(\mathrm{kg})\right] / \mathrm{DM}_{\text {Concentrate }}(\mathrm{kg})$. 
(Table 1) was supplied in a trough separated from the hay available to animals for 60 minutes during each period for total intake. The hay was chopped resulting in particles with mean size of $0.5 \mathrm{~cm}$, and the supply maintained orts not below $10 \%$ of the total provided. Intake was calculated by the difference of the total supplied and the orts and DM intake was calculated based on the average body weight of animals [(final body weight + initial body weight)/2].

In the end of the experimental period, the animals were slaughtered with an average body weight of $34.5 \mathrm{~kg}$. After slaughter, carcasses were weighted to establish the hot carcass weight (HCW) and the hot carcass yield ( $\mathrm{HCY} \%=\mathrm{HCW} /$ Weight at Slaughter $\mathrm{x}$ 100). Carcasses were subsequently cooled in a cold chamber at $2^{\circ} \mathrm{C}$ for 48 hours and once again weighted to obtain the cold carcass weight $(\mathrm{CCW})$, cold carcass yield $(\mathrm{CCY} \%=\mathrm{CCW} /$ Weight at Slaughter $\mathrm{x} 100)$, and percentage of cooling losses $(\mathrm{CLL}=\mathrm{HCW}-\mathrm{CCW} / \mathrm{HCW} \times 100)$.

After the cooling period, carcasses were cut in half; length was measured in the left half carcass ( $\mathrm{CL}$ - from the ischiopubic symphysis to the first rib, in the midpoint), the leg length (LL - distance between the greater trochanter of femur until the tarsometatarsal joint), and cushion thickness (CT - at maximum width). The compactness of the carcasses was carried out through the relation: cold carcass weight /internal length. Left half carcass was separated in shoulder, leg (section between the first and the second sacral vertebrae) and other parts (half carcass subtracted from the leg and shoulder). The area of the Longissimus dorsi muscle (loin eye area - LEA), measured using the grid points methodology, and thickness of subcutaneous fat (fat thickness - FT) were measured in the section made between the $12^{\text {th }}$ and $13^{\text {th }}$ ribs (MENEZES et al., 2008; COSTA et al., 2012).

Analyses of regression were not significant ( $\mathrm{P}>0.15)$; therefore, the parameters were subjected to analysis of variance in a model including initial weight body as co-variable. Adjusted measures were compared using Tukey test at 5\% probability level through procedure GLM of statistical package SAS (2002). The statistical model employed was $\mathrm{Y}_{\mathrm{ij}}=\beta_{0}+\mathrm{B}_{1} \mathrm{X}_{\mathrm{ij}}+\mathrm{T}_{\mathrm{i}}+\varepsilon_{\mathrm{ij}}$, where $\mathrm{Y}_{\mathrm{ij}}=$ observation $\mathrm{j}$ in the treatment $i, \beta_{0}=$ intercept, $B_{1}=$ coefficient of regression, $X_{i j}=$ initial weight co-variable, $T_{i}=$ fixed treatment effect $\mathrm{i}(\mathrm{i}=1 \mathrm{a} 4), \varepsilon_{\mathrm{ij}}=$ random error.

\section{RESULTS AND DISCUSSION}

The mean body weight of the animals during the experimental period was 29.35, 29.88, 30.25 and $29.62 \mathrm{~kg}$, respectively for treatments with zero, five, 10 and $15 \%$ of glycerin, with no differences among the treatments $(\mathrm{P}>0.05)$.

Table 2 presents the means of concentrate intake, forage intake and total dry matter intake, forage: concentrate ratio in the diet, dry matter intake in relation of body weight and feed conversion of kid goats fed with diets containing different levels of glycerin inclusion. The table also indicates that the level of glycerin had no effect $(\mathrm{P}>0.05)$ on the forage intake; however, it points out a reduction $(\mathrm{P}<0.05)$ on the intake of concentrate and in the total DM with increase in the levels of glycerin inclusion. As the inclusion of glycerin was carried out in the concentrate, it is speculated that the increase in the level of glycerin made the concentrate less acceptable reducing its consumption however without affecting

Table 2 - Means and standard error of forage and concentrate intake, total dry matter intake (DMI), forage: concentrate ratio in the diet, dry matter intake in relation to body weight (DMI/BW), dry matter intake per kilogram of metabolic weight (DM Int.) and feed conversion of kid goats supplied with glycerin.

\begin{tabular}{|c|c|c|c|c|}
\hline & 0 & 5 & 10 & 15 \\
\hline Forage intake $(\mathrm{g})$ & $252.9 \pm 34.9$ & $329.1 \pm 31.0$ & $300.1 \pm 31.0$ & $288.0 \pm 31.2$ \\
\hline Concentrate intake $(\mathrm{g})$ & $579.2 \pm 26.0^{\mathrm{a}}$ & $569.9 \pm 23.1^{\mathrm{ab}}$ & $506.2 \pm 23.1^{\mathrm{bc}}$ & $445.6 \pm 23.2^{\mathrm{c}}$ \\
\hline DMI (g) & $832.1 \pm 41.8^{\mathrm{ab}}$ & $899.0 \pm 37.2^{\mathrm{a}}$ & $806.3 \pm 37.2^{\mathrm{ab}}$ & $733.6 \pm 37.4^{b}$ \\
\hline Concentrate $(\%)$ & $70.0 \pm 3.1^{\mathrm{a}}$ & $63.5 \pm 2.8^{\mathrm{ab}}$ & $62.7 \pm 2.8^{\mathrm{ab}}$ & $61.1 \pm 2.8^{\mathrm{b}}$ \\
\hline Forage $(\%)$ & $30.0 \pm 3.1^{\mathrm{a}}$ & $36.5 \pm 2.8^{\mathrm{a}}$ & $37.3 \pm 2.8^{\mathrm{a}}$ & $38.9 \pm 2.8^{b}$ \\
\hline DMI/BW (\%) & $2.77 \pm 0.11^{\mathrm{ab}}$ & $2.98 \pm 0.10^{\mathrm{b}}$ & $2.71 \pm 0.10^{\mathrm{ab}}$ & $2.53 \pm 0.10^{\mathrm{a}}$ \\
\hline DM Int. ( $\mathrm{g} \mathrm{kg}^{-0,75}$ day $\left.^{-1}\right)$ & $64.99 \pm 2.79^{\mathrm{ab}}$ & $69.76 \pm 2.50^{\mathrm{b}}$ & $63.17 \pm 2.50^{\mathrm{ab}}$ & $58.69 \pm 2.50^{\mathrm{a}}$ \\
\hline Feed conversion $(\mathrm{kg})$ & $5.18 \pm 0.39$ & $5.31 \pm 0.34$ & $4.93 \pm 0.34$ & $5.57 \pm 0.35$ \\
\hline
\end{tabular}

Values with different letters in the same row differ statistically $(\mathrm{P}<0.05)$ through Tukey test. 
hay intake. JESUS et al. (2010) suggested that the consumption reduction may be associated with factors such as the energy content in the diet and acceptance, factors involved in the regulation of ruminants' consumption.

Reinforcing these findings, CORREIA et al. (2006) verified that the chemotactic effect of soluble carbohydrates restrict the consumption before the maximum fill level of the rumen, which could also explain the decrease in the consumption of concentrate with $15 \%$ inclusion of glycerin. LAGE et al. (2010) stated that the production of propionate via metabolism of the glycerol presented in the diet is a factor that could contribute to the decrease in the DM consumption. Among the products metabolized in the liver of ruminants, propionate is probably the first to indicate that a meal is finished due to the increase in its flow towards the liver. The possible increase in propionate in the rumen through glycerol led to higher amounts in the liver, which may have contributed to satiety, and consequently lower DM intake.

The forage: concentrate ratio was influenced $(\mathrm{P}<0.05)$ by the glycerin in the diet, a response of the reduction in the ingestion of concentrate with the increase in glycerin inclusion.

The DM intake in relation to the body weight of the animals varied from 2.53 to $2.98 \%$, with influence $(\mathrm{P}<0.05)$ of the glycerin level. Consumption by animals with diet containing $15 \%$ glycerin in the DM was lower than that by animals with a diet containing 5\%; however, both cases presented a consumption lower than the estimated through NRC (2007). Values found were lower than those described by MORAES (2007) for animals with lower weight having verified mean consumption of $3.73 \%$, higher than estimated through NRC (2007). The DM intake maintained equal tendency with the use of metabolic size as unit, with consumption varying from 58.69 to $69.76 \mathrm{~g} \mathrm{~kg}^{-0.75}$ day $^{-1}$.

Feed conversion (FC) in this study varied from 4.93 to $5.57 \mathrm{~kg} \mathrm{MS} \mathrm{kg}^{-1}$ of body weight gain, but with no influence of the level of glycerin inclusion in the diet. The results presented are similar to those described by CORREIA et al. (2006), observed in crossbred female kid goats, Saanen x Crioula, feedlot and fed with pineapple agro-industrial residue, a FC varying from 5.62 to $5.97 \mathrm{~kg} \mathrm{MS} \mathrm{kg}^{-1}$ of weight gain.

The inclusion of up to $15 \%$ of glycerin in the DM of the diet had no effect on the exploitation and conversion of dry matter in body weight by the animals, corroborating the findings by SANTOS et al. (2015).

Table 3 presents the initial and final averages body weight, daily weight gain (DWG) and characteristics of the carcass of goats fed with diet containing different levels of glycerin inclusion. No effect $(\mathrm{P}>0.05)$ of the glycerin level in the diet was observed on the final body weight and DWG of animals, from 33.27 to $35.20 \mathrm{~kg}$, and 0.136 to $0.168 \mathrm{~kg}$, respectively, with gains lower than those described by

Table 3 - Means and standard errors for body weight, body weight gain and carcass traits of kid goats supplied with glycerin.

\begin{tabular}{|c|c|c|c|c|}
\hline & 0 & 5 & 10 & 15 \\
\hline Initial body weight (kg) & $23.97 \pm 2.23$ & $24.56 \pm 1.99$ & $25.50 \pm 1.99$ & $25.98 \pm 1.99$ \\
\hline Final body weight (kg) & $34.73 \pm 0.84$ & $35.20 \pm 0.75$ & $35.01 \pm 0.75$ & $33.27 \pm 0.75$ \\
\hline Daily weight gain (kg) & $0.161 \pm 0.014$ & $0.168 \pm 0.012$ & $0.165 \pm 0.012$ & $0.136 \pm 0.012$ \\
\hline Hot carcass weight $(\mathrm{kg})$ & $16.92 \pm 0.32^{\mathrm{a}}$ & $16.91 \pm 0.28^{\mathrm{a}}$ & $16.69 \pm 0.28^{\mathrm{a}}$ & $15.60 \pm 0.28^{\mathrm{b}}$ \\
\hline Hot carcass yield (\%) & $49.39 \pm 1.08$ & $48.30 \pm 0.96$ & $47.60 \pm 0.96$ & $48.23 \pm 0.96$ \\
\hline Cold carcass weight (kg) & $16.40 \pm 0.33^{\mathrm{a}}$ & $16.43 \pm 0.29^{\mathrm{a}}$ & $16.20 \pm 0.29^{\mathrm{a}}$ & $15.08 \pm 0.29^{\mathrm{b}}$ \\
\hline Cold carcass yield (\%) & $47.90 \pm 0.97$ & $46.88 \pm 0.86$ & $46.17 \pm 0.86$ & $46.58 \pm 0.87$ \\
\hline Cooling losses (\%) & $3.03 \pm 0.49$ & $2.93 \pm 0.43$ & $2.94 \pm 0.43$ & $3.39 \pm 0.44$ \\
\hline Leg length (cm) & $33.79 \pm 0.59$ & $33.93 \pm 0.52$ & $34.72 \pm 0.52$ & $33.25 \pm 0.53$ \\
\hline Cushion thickness (cm) & $7.97 \pm 0.39$ & $7.88 \pm 0.35$ & $8.18 \pm 0.35$ & $7.87 \pm 0.35$ \\
\hline Carcass length (cm) & $61.68 \pm 0.49$ & $62.19 \pm 0.44$ & $62.82 \pm 0.44$ & $61.33 \pm 0.44$ \\
\hline Fat thickness (mm) & $1.11 \pm 0.31$ & $1.29 \pm 0.28$ & $1.11 \pm 0.28$ & $1.21 \pm 0.28$ \\
\hline Loin eye area $\left(\mathrm{cm}^{2}\right)$ & $9.85 \pm 0.73$ & $8.60 \pm 0.65$ & $9.00 \pm 0.65$ & $9.60 \pm 0.66$ \\
\hline Leg weight (kg) & $2.38 \pm 0.05$ & $2.44 \pm 0.05$ & $2.38 \pm 0.05$ & $2.31 \pm 0.05$ \\
\hline Shoulder weight (kg) & $1.47 \pm 0.04$ & $1.46 \pm 0.04$ & $1.46 \pm 0.04$ & $1.34 \pm 0.04$ \\
\hline Other parts weight $(\mathrm{kg})$ & $4.35 \pm 0.11^{\mathrm{a}}$ & $4.31 \pm 0.09^{\mathrm{a}}$ & $4.25 \pm 0.09^{\mathrm{a}}$ & $3.89 \pm 0.10^{\mathrm{b}}$ \\
\hline Compactness $\left(\mathrm{kg} \mathrm{cm}^{-1}\right)$ & $0.26 \pm 0.006$ & $0.26 \pm 0.005$ & $0.26 \pm 0.005$ & $0.25 \pm 0.005$ \\
\hline
\end{tabular}

Values with different letters in the same row differ statistically $(\mathrm{P}<0.05)$ through Tukey test. 
PEREIRA FILHO et al. (2005), who obtained $0.211 \mathrm{~kg}$ of DWG for crossbred Boer goats fed individually with complete feed. LAGE et al. (2009) observed linear descending effect of glycerin inclusion levels in the diet (zero, three, six, nine and $12 \%$ in the DM of the diet) of lambs in animals weight, which led the authors to the conclusion that glycerin inclusion in the diet of feedlot animals promotes alterations of negative impacts in the DWG, resulting in lower body weight at slaughter.

Although no differences were indicated for the final body weight, a reduction $(\mathrm{P}<0.05)$ of $\mathrm{HCW}$ and $\mathrm{CCW}$ of animals fed with $15 \%$ of glycerin was observed, suggesting that in this group of animals a lower tissue deposition had occurred in the carcass. It is possible to infer that the lower consumption of concentrate indicated for the animals in this group may have led to a lower consumption of metabolizable energy, resulting in lower carcass weight, which corroborates the findings by PALMIERI et al. (2012) who, worked with crossbred Boer goats and reported similar consumption of metabolizable energy resulting in similar body weight.

However, despite the reduction in $\mathrm{HCW}$ and $\mathrm{CCW}$, no effect $(\mathrm{P}>0.05)$ of glycerin level in the diet was observed in HCY and CCY. HCY varied from 47.60 to $49.39 \%$, and CCY varied from 46.17 to $47.90 \%$, valued within the rate of those described in the literature (CUNHA et al., 2002; EL-WAZIRY et al., 2011; SOLAIMAN et al., 2011; SALLES et al., 2013).

CLL varied from 2.93 to $3.39 \%$ and had no effect $(\mathrm{P}>0.05)$ of glycerin levels in the diet; the values are similar to those mentioned by SOLAIMAN et al. (2011), reported for grazing crossbred Boer goats, castrated and uncastrated, values of 4.00 and $3.00 \%$, respectively. According to LAGE et al. (2009), the CLL of a carcass is an important parameter to assess quality of the product and presents inverse relationship with the juiciness and softness of the meat.

It is also possible to observe (Table 3), that no significant effect $(\mathrm{P}>0.05)$ of the glycerin level occurred for the variables of leg length, cushion thickness, carcass length, fat thickness, loin eye area, leg weight (LW), shoulder weight (SW) and compactness of the carcass of kid goats fed with diet containing different levels of glycerin inclusion; however, a difference $(\mathrm{P}<0.05)$ was verified for the variable other parts weight (OPW).

It was reported that the treatment with $15 \%$ of glycerin had effect on OPW, being $0.46 \mathrm{~kg}$ lower than the control treatment, which was probably due to lower carcass weight values, but with no differences in the weight of major commercial cuts (leg and shoulder).
Considering the mean cold carcass weight of the assessed animals $(16.02 \mathrm{~kg})$, the leg yield represented, in average, $29.58 \%$ of total carcass weight, and the shoulder yield represented $17.85 \%$, values lower than those reported by MARQUES et al. (2013) regarding goats of equal weight and racial group.

For cushion thickness, carcass length, fat thickness, loin eye area, leg weight, shoulder weight and other parts the averages were $7.97 \mathrm{~cm}, 62.00 \mathrm{~cm}$, $1.18 \mathrm{~mm}, 9.26 \mathrm{~cm}^{2}, 2.37 \mathrm{~kg}, 1.43 \mathrm{~kg}$ and $4.20 \mathrm{~kg}$, respectively. By comparing these data to those reported by CUNHA et al. (2002), with animals $1 / 2$ Boer $\mathrm{x}$ Saanen, with lower weight at slaughter $(22.5 \mathrm{~kg})$, we have higher values of FT and compactness, demonstrating a potential of meat production for this type of crossing. GOMES et al. (2011) mentioned that the index of carcass compactness may be employed to assess the production of tissues in the carcass of animals with similar body weight, with a direct relation to the proportion of muscle and fat in the animal carcass. Values of LEA (Table 3), a characteristic linked to the size of the body, verified in this study, are within the rate of values mentioned in the literature for goats (CUNHA et al., 2002; EL-WAZIRY et al., 2011; SALLES et al., 2013). According to SALLES et al. (2013), LEA is the most representative measurement of an animal muscle mass, and higher values for this measure represent better carcasses regarding muscle amount.

\section{CONCLUSION}

The inclusion up to $15 \%$ of glycerin in the diet of kid goats Boer crossbred, although does not affect feed conversion and performance, compromises the intake and carcass weight.

\section{ACKNOWLEDGEMENTS}

The authors thank the Fundação Araucária and Instituto Agronômico do Paraná (IAPAR) for the financial support.

\section{REFERENCES}

ABDALLA, A.L. et al. Utilização de subprodutos da indústria de biodiesel na alimentação de ruminantes. Revista Brasileira de Zootecnia, v.37, p.260-268, 2008. (Supl. esp.). Available from: $<$ http://www.scielo.br/pdf/rbz/v37nspe/a30v37nsp.pdf>. Accessed: Aug. 19, 2014. doi: 10.1590/S1516-35982008001300030.

CORREIA, M.X.C. et al. Utilização de resíduo agroindustrial de abacaxi desidratado em dietas para caprinos em crescimento: digestibilidade e desempenho. Revista Brasileira de Zootecnia, v.35, n.4, p.1822-1828, 2006. (Supl.). Available from: <http:// www.scielo.br/pdf/rbz/v35n4s0/a33v354s.pdf > Accessed: Aug. 21, 2014. doi: 10.1590/S1516-35982006000600033. 
COSTA, R.G. et al. Utilização de diferentes metodologias para determinação da área de olho de lombo em ovinos. Archivos de Zootecnia, v.61, n.236, p.615-618, 2012. Available from: <http:// scielo.isciii.es/pdf/azoo/v61n236/art14.pdf>. Accessed: Feb. 12, 2015. doi: 10.4321/S0004-05922012000400014.

CUNHA, E.A. et al. Desempenho e características de carcaça de cabritos Saanen e mestiços Boer. In: REUNIÃO ANUAL DA SOCIEDADE BRASILEIRA DE ZOOTECNIA, 39., 2002, Recife, PE. Anais... Recife: UFRPE, 2002. (CD-Rom).

EL-WAZIRY, A.M. et al. Performance, carcass characteristics and meat quality of intact and castrated Ardhi goat kids fed high energy diet. Journal of Animal and Veterinary Advances, v.10, n.16, p.2157-2162, 2011. Available from: <http://docsdrive.com/pdfs/medwelljournals/ javaa/2011/2157-2162.pdf >. Accessed: Aug. 19, 2014.

GOMES, H.F.B. et al. Características de carcaça de caprinos de cinco grupos raciais criados em confinamento. Revista Brasileira de Zootecnia, v.40, n.2, p.411-417, 2011. Available from: $<$ http:// www.scielo.br/pdf/rbz/v40n2/24.pdf>. Accessed: Aug. 20, 2014. doi: 10.1590/S1516-35982011000200024.

JESUS, I.B. et al. Níveis de óleo de licuri [Syagrus coronata (Martius) Beccari] na dieta de cabritos 3/4 Boer. Revista Brasileira de Saúde e Produção Animal, v.11, n.4, p.1163-1175, 2010. Available from: <http://revistas.ufba.br/index.php/rbspa/article/ view/1973/1042>. Accessed: Aug. 20, 2014.

LAGE, J.F. et al. Peso e rendimento de carcaça de cordeiros em terminação alimentados com glicerina bruta. In: REUNIÃO ANUAL DA SOCIEDADE BRASILEIRA DE ZOOTECNIA, 46., 2009, Maringá, PR. Anais... Maringá: UEM, 2009. (CD-Rom).

LAGE, J.F. et al. Glicerina bruta na dieta de cordeiros terminados em confinamento. Pesquisa Agropecuária Brasileira, v.45, n.9, p.1012-1020, 2010. Available from: <http://www.scielo.br/pdf/ pab/v45n9/a11v45n9.pdf>. Accessed: Aug. 19, 2014.

MARQUES, R.O. et al. Rendimento de corte, proporção tecidual da carcaça e composição centesimal da carne de caprinos jovens em função do grupo racial e do peso corporal de abate. Arquivo Brasileiro de Medicina Veterinária e Zootecnia, v.65, n.5, p.1561-1569, 2013. Available from: <http://www.scielo.br/pdf/ abmvz/v65n5/a38v65n5.pdf>. Accessed: Aug. 22, 2014 . doi: $10.1590 / \mathrm{S} 0102-09352013000500038$.

MENEZES, L.F.O. et al. Características de carcaça, componentes não-carcaça e composição tecidual e química da $12^{\text {a }}$ costela de cordeiros Santa Inês terminados em pasto com três gramíneas no período seco. Revista Brasileira de Zootecnia, v.37, n.7, p.1286-1292, 2008. Available from: <http://www.scielo.br/pdf/ rbz/v37n7/21.pdf>. Accessed: Feb. 12, 2015. doi: 10.1590/S151635982008000700021 .

MENTEN, J.F.M. et al. Glicerol na alimentação animal. In: SIMPÓSIO SOBRE MANEJO E NUTRIÇÃO DE AVES E SUÍNOS, 2008, Campinas, SP. Anais... Campinas: CBNA, 2008. p.101-114.

MORAES, S.A. Subprodutos da agroindústria e indicadores externos de digestibilidade aparente em caprinos. 2007, 46f. Tese (Doutorado em Zootecnia) - UFMG, Belo Horizonte, MG.

NRC (NATIONAL RESEARCH COUNCIL). Nutrient requirements of small ruminants. Washington. D.C.: National Academy, 2007. 362p.

PALMIERI, A.D. et al. Effects of substituting soybean meal for sunflower cake in the diet on the growth and carcass traits of crossbred boer goat kids. Asian-Australasian Journal of Animal Sciences, v.25, n.1, p.59-65, 2012. Available from: <http://www. ncbi.nlm.nih.gov/pmc/articles/PMC4092926/pdf/ajas-25-1-59-9. pdf $>$. Accessed: Sept. 15, 2014. doi: 10.5713/ajas.2011.11140.

PEREIRA FILHO, J.M. et al. Efeito da restrição alimentar no desempenho produtivo e econômico de cabritos F1 Boer x Saanen. Revista Brasileira de Zootecnia, v.34, n.1, p.188-196, 2005.

SALLES, F.M. et al. Características de carcaça de cabritos criados em dois sistemas de terminação. Arquivo Brasileiro de Medicina Veterinária e Zootecnia, v.65, n.6, p.1867-1875, 2013. Available from: <http://www.scielo.br/pdf/abmvz/v65n6/39.pdf >. Accessed: Sept. 15, 2014. doi: 10.1590/S0102-09352013000600039.

SANTOS, D.A. et al. Desempenho produtivo de cabritos alimentados com glicerina bruta. Ciência Rural, v.45, n.4, p.690-696, 2015. Available from: <http://www.scielo.br/pdf/cr/ v45n4/1678-4596-cr-45-04-00690.pdf>. Accessed: Jul. 08, 2015. doi: 10.1590/0103-8478cr20140536.

SAS. SAS/STAT. User's guide. Ed SAS Institute. Cary, NC, EUA. 2002. (CD-Rom).

SOLAIMAN, S. et al. Growth performance, carcass characteristics and meat quality of Boer-cross Wether and Buck goats grazing marshall ryegrass. Asian-Australasian Journal of Animal Sciences, v.24, n.3, p.351-357, 2011. Available from: <http:// ajas.info/upload/pdf/24-41.pdf $>$. Accessed: Sept. 16, 2014. doi: 10.5713/ajas.2011.10081. 